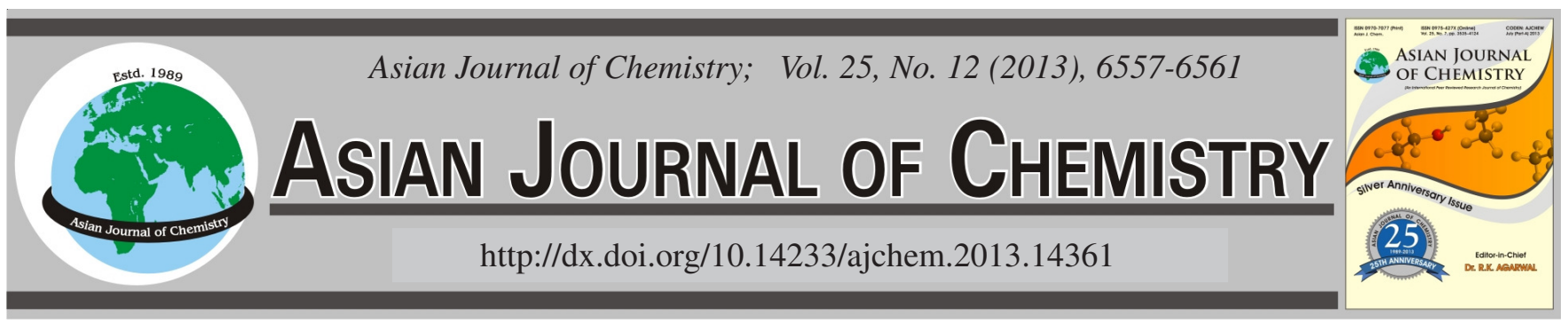

\title{
Kinetic and Thermodynamic Studies of Free and Alginate/ Agar-Agar Immobilized $\alpha$-Amylase Catalyzed Reaction
}

\author{
Soumen Pramanik, Khomendra Kumar Sarwa, Ashoke Kumar Dolui and Atul Kumar*
}

Department of Pharmaceutical Sciences, Dibrugarh University, Dibrugarh-786 004, India

*Corresponding author: E-mail: atul2008@gmail.com

\begin{abstract}
The present study deals with the immobilization of $\alpha$-amylase into alginate and agar-agar medium and determination of kinetics as well as thermodynamic parameters of both free and immobilized enzyme catalyzed reaction to predict the extent of reaction and the position of equilibrium. At optimized condition, the $\mathrm{K}_{\mathrm{m}}$ value derived from Lineweaver Burk plot for free enzyme $(0.40 \%$ w/v $)$ was lower than the immobilized enzyme $\left(0.52 \% \mathrm{w} / \mathrm{v}\right.$ for alginate and $0.76 \% \mathrm{w} / \mathrm{v}$ for agar-agar immobilized). The free enzyme had an $\mathrm{E}_{\mathrm{a}} \mathrm{value}$ of $1609 \mathrm{cal} /$ mol compared to those of immobilized enzyme $(6495 \mathrm{cal} / \mathrm{mol}$ for alginate and $3542 \mathrm{cal} / \mathrm{mol}$ for agar-agar immobilized). Computed $\Delta \mathrm{S}$ value for free enzyme is more negative than the immobilized enzyme. The increasing value $\Delta \mathrm{G}^{\mathrm{o}}$ in immobilized enzyme system indicates that the enzyme-substrate reaction is slower during immobilization. However immobilized enzyme could be reused even after 12 days of storage.
\end{abstract}

Key Words: $\alpha$-Amylase, Kinetics, Enzymes, Immobilization, Alginate, Agar-agar.

\section{INTRODUCTION}

The uses of immobilized enzymes are increasing in biotechnology, biomedicine, food technology and analytical chemistry due to their various advantages over free enzymes including easy separation of the reactants, products and reaction media, easy recovery of the enzyme and reusability.

One of the largest selling industrial enzymes is $\alpha$-amylase that has several industrial applications ${ }^{1-3}$. Immobilization of such enzyme increases its economic value for industrial processors by substituting costly free enzyme with immobilized one ${ }^{4}$.

Several methods of enzyme immobilization have been reported so far, such as-adsorption ${ }^{5}$, adsorption and crosslinking ${ }^{6}$, cross-linking ${ }^{7}$, ion-exchange resins ${ }^{8}$, entrapment ${ }^{9}$, microencapsulation ${ }^{10}$, copolymerization ${ }^{11}$ and covalent attachment ${ }^{12}$. In the present study, alginate and agar-agar were chosen as carrier materials due to their cost effectiveness and good immobilization efficiency. In addition, alginate, a naturally occurring polymer consisting of mannuronic acid and gluronic acid, formes inert aqueous environment inside its matrix and high gel porosity that allows high diffusion rates of macromolecules ${ }^{13}$. On the other hand, agar-agar is a natural polysaccharide with a strong gelling ability and good acid stability characteristics, showing no protein reactivity.

To predict the extent of reaction and to know the position of equilibrium for any enzymatic reaction, enzyme kinetic information is necessary and that prediction has important applications in biochemistry, industrial enzymology and in metabolic control analysis also. Thermodynamics and activation parameters also provide a detailed mechanism for many chemical and biological reactions ${ }^{14}$. Hence in the present work kinetics as well as thermodynamic aspects for both free and immobilized amylase-catalyzed reactions has been studied.

\section{EXPERIMENTAL}

$\alpha$-Amylase and soluble starch were purchased from Sigma Chemical Co., USA and Central Drug House Pvt. Ltd., Mumbai, India, respectively. Sodium alginate and agar-agar powder were from Loba Chemie Pvt. Ltd., Mumbai, India. All other chemicals used were of analytical grade.

Determination of optimum $\mathbf{p H}$ and temperature: To determine the optimum $\mathrm{pH}$ for maximum enzyme activity, the reaction was carried out at different $\mathrm{pH}$ using $0.2 \mathrm{M}$ acetate buffer of $\mathrm{pH} 3.6,4.0,4.4,4.8,5.0,5.2$ and 5.6. Duplicate sets of seven tests tubes were arranged and $0.5 \mathrm{~mL}$ enzyme solution was added to each test tube containing $1.75 \mathrm{~mL}$ of starch, $2.25 \mathrm{~mL}$ of buffer (pH range 3.6, 4.0, 4.4, 4.8, 5.0, 5.2 and 5.6) and $1.0 \mathrm{~mL}$ of distilled water. All the test tubes were incubated at $40{ }^{\circ} \mathrm{C}$ in a thermostatic water bath. After $20 \mathrm{~min}$, $0.5 \mathrm{~mL}$ of $1 \mathrm{M} \mathrm{HCl}$ was added to each test tube to stop the reaction. $0.2 \mathrm{~mL}$ of the reaction mixture from each test tube was diluted with $14.5 \mathrm{~mL}$ with distilled water. Then $0.2 \mathrm{~mL}$ of 
iodine reagent and $0.1 \mathrm{~mL}$ of $1 \mathrm{M} \mathrm{HCl}$ were added to each of them. The absorbance of reaction mixture was measured at $610 \mathrm{~nm}$ in a UV-VIS spectrophotometer (Shimadzu UV-1800) against a blank ${ }^{14-17}$.

Optimum temperature of the enzyme was determined by above procedure using buffer of optimum $\mathrm{pH}$ (5.0) and incubating at different temperatures viz., 30, 35, 40, 45 and $50{ }^{\circ} \mathrm{C}$ using a thermostatic water bath.

Immobilization of $\alpha$-amylase with alginate: For immobilization $0.5 \mathrm{~mL}$ of $\alpha$-amylase solution ( $1 \% \mathrm{w} / \mathrm{v}$ ) was added to $1.5 \mathrm{~mL}$ of $2 \%$ sodium alginate solution and the mixture was extruded drop wise into a gently stirred $2 \% \mathrm{CaCl}_{2}$ solution by maintaining a height of $2 \mathrm{~cm}$. All the beads were cured for $20 \mathrm{~min}$ and separated by filtration. They were washed twice with distilled water ${ }^{15}$.

Immobilization of $\boldsymbol{\alpha}$-amylase with agar-agar: Mixture of $0.5 \mathrm{~mL} \alpha$-amylase $(1 \% \mathrm{w} / \mathrm{v})$ and $1.5 \mathrm{~mL} 3.0 \%$ molten agar-agar at about $45^{\circ} \mathrm{C}$ was placed in the well of a microtiter plate and beads were formed when the mixture was cooled down.

Kinetics study: Duplicate sets of six test tubes were taken, each containing $2.25 \mathrm{~mL}$ of acetate buffer ( $\mathrm{pH} 5.0), 1 \mathrm{~mL}$ of distilled water and $1.75 \mathrm{~mL}$ of different concentration viz., 2.4, 2.0, 1.6, 1.2, 0.8 and $0.0 \%$ (blank) of soluble starch and maintained at $35^{\circ} \mathrm{C}$ in a thermostatic water bath. To each test tube $0.5 \mathrm{~mL}$ amylase solution ( $1 \%$ ) was added. After $10 \mathrm{~min}$, reaction in each test tube was stopped by addition of $0.5 \mathrm{~mL}$ of $1 \mathrm{M} \mathrm{HCl}$. $0.2 \mathrm{~mL}$ of the reaction mixture was diluted by addition of $14.5 \mathrm{~mL}$ distilled water followed by addition of $0.2 \mathrm{~mL}$ of $2 \%$ iodine reagent and $0.1 \mathrm{~mL}$ of $1 \mathrm{M} \mathrm{HCl}$. The absorbance was measured at $610 \mathrm{~nm}$ in a UV-VIS spectrophotometer. The above procedure was repeated at 40 and $45^{\circ} \mathrm{C}$.

Above procedure was repeated for the kinetic study of immobilized enzyme but instead of using $0.5 \mathrm{~mL}$ free enzyme, alginate or agar immobilized enzyme beads prepared from $0.5 \mathrm{~mL} 1 \%$ enzyme were used.

Reusability: Starch degradation properties of the prepared immobilized enzyme beads were determined using $1.2 \% \mathrm{w} / \mathrm{v}$ starch as substrate at optimum $\mathrm{pH}$ (5.0) and temperature (40 $\left.{ }^{\circ} \mathrm{C}\right)$. Then the beads were filtrated through filter paper, washed thrice with distilled water and stored in a refrigerator $\left(4{ }^{\circ} \mathrm{C}\right)$. On 6 th day and 12 th day again the starch degradation activities of the beads were determined. The beads were also visually inspected for any sign of physical deformity.

\section{RESULTS AND DISCUSSION}

Enzyme activities at different $\mathrm{pH}$ and temperature are presented in Figs. 1 and 2, respectively and from the figure optimum $\mathrm{pH}$ and temperature of $\alpha$-amylase are found to be 5.0 and $40^{\circ} \mathrm{C}$, respectively.

Starch degradation activities of the free enzyme ( $\alpha$-amylase), alginate immobilized and agar-agar immobilized enzyme at different substrate concentration and different temperature are presented in Tables 1-3, respectively. For enzyme kinetic study, Michaelis-Menten equation i.e., $\mathrm{V}=\mathrm{V}_{\mathrm{m}} \frac{\mathrm{S}}{\mathrm{K}_{\mathrm{m}}+\mathrm{S}}$ is hyperbolic, Lineweaver Burk transformed the hyperbolic

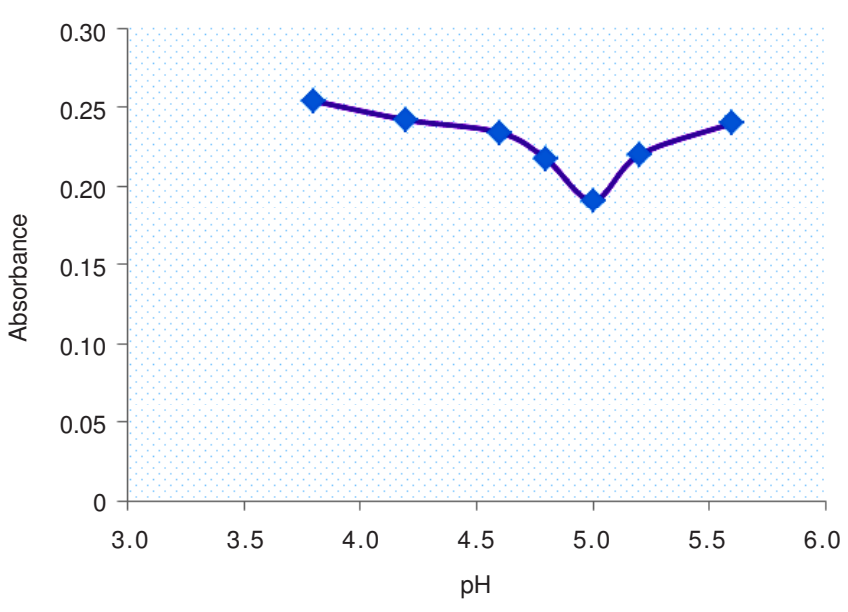

Fig. 1. Determination of optimum $\mathrm{pH}$ of $\alpha$-amylase

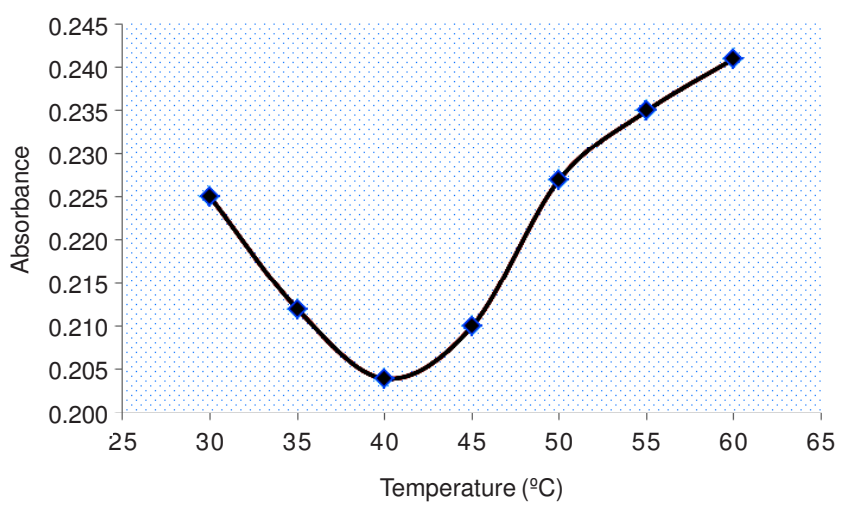

Fig. 2. Determination of optimum temperature of $\alpha$-amylase

equation into a linear equation which is $\frac{1}{\mathrm{~V}}=\frac{1}{\mathrm{~V}_{\mathrm{m}}}+\frac{\mathrm{K}_{\mathrm{m}}}{\mathrm{V}_{\mathrm{m}}} \frac{1}{\mathrm{~S}}$ where, $\mathrm{V}$ is the velocity of reaction, $\mathrm{V}_{\mathrm{m}}$ is maximum attainable reaction velocity, $[\mathrm{S}]$ is the substrate concentration and $\mathrm{K}_{\mathrm{m}}$ is Michaelis-Menten constant. The reciprocal velocity (1/V) was plotted against the reciprocal substrate concentrations 1/[S] in Figs. 3-5 and extrapolation of the line gave the respective values of $\mathrm{K}_{\mathrm{m}}$ which are found to be $0.40 \% \mathrm{w} / \mathrm{v}$ for the free enzyme and $0.52 \% \mathrm{w} / \mathrm{v}$ and $0.76 \% \mathrm{w} / \mathrm{v}$ for alginate immobilized and agar-agar immobilized enzyme, respectively. The value of free amylase is lower than that of the immobilized amylase in alginate or agar-agar. Low value of $\mathrm{K}_{\mathrm{m}}$ indicate high affinity of the enzyme for the substrate ${ }^{16}$. The $K_{m}$ value mainly deals with the affinity of the substrate for the active site of an enzyme. This result indicates that affinity of free enzyme is more for the substrate than by the immobilized enzyme. The increase in apparent $\mathrm{K}_{\mathrm{m}}$ value might be either due to structural changes in the enzyme induced by the applied immobilization procedure or due to the lower accessibility of the substrate to the active site of the immobilized enzyme ${ }^{17}$.

Different thermodynamic parameters like energy of activation $\left(\mathrm{E}_{\mathrm{a}}\right)$, Arrhenius factor $(\mathrm{A})$, standard enthalpy change $(\Delta \mathrm{H})$, Gibbs free energy $\left(\Delta \mathrm{G}^{\mathrm{o}}\right)$, standard entropy change $(\Delta \mathrm{S})$, probability factor $(\mathrm{P})$ and equilibrium constant $(\mathrm{K})$ values of enzyme catalyzed reaction for both free and immobilized enzyme were evaluated from the slope and intercept of the Arrhenius plots. The following equations were used to get the computed data. 


\begin{tabular}{cccccc}
\hline \multicolumn{5}{c}{ TABLE-1 } \\
& \multicolumn{5}{c}{ STARCH DEGRADATION ACTIVITY OF FREE $\alpha$-AMYLASE } \\
\cline { 2 - 6 } Temperature $\left({ }^{\circ} \mathrm{C}\right)$ & \multicolumn{5}{c}{ Concentration of soluble starch $(\% \mathrm{w} / \mathrm{v})$} \\
\cline { 2 - 6 } & 2.4 & 2.0 & 1.6 & 1.2 & 0.8 \\
\hline 45 & $1.088 \pm 0.010$ & $0.982 \pm 0.005$ & $0.811 \pm 0.004$ & $0.582 \pm 0.003$ & $0.356 \pm 0.006$ \\
40 & $0.899 \pm 0.007$ & $0.812 \pm 0.001$ & $0.619 \pm 0.014$ & $0.437 \pm 0.001$ & $0.257 \pm 0.010$ \\
35 & $1.009 \pm 0.009$ & $0.839 \pm 0.004$ & $0.711 \pm 0.021$ & $0.507 \pm 0.004$ & $0.322 \pm 0.001$ \\
\hline
\end{tabular}

\begin{tabular}{cccccc} 
& \multicolumn{5}{c}{ TABLE-2 } \\
& \multicolumn{5}{c}{ STARCH DEGRADATION ACTIVITY OF SODIUM ALGINATE IMMOBILIZED $\alpha$-AMYLASE } \\
\hline \multirow{3}{*}{ Temperature $\left({ }^{\circ} \mathrm{C}\right)$} & \multicolumn{5}{c}{ Concentration of soluble starch $(\%$ w/v) } \\
\cline { 2 - 6 } & 2.4 & 2.0 & Absorbance & 1.6 & 0.8 \\
\cline { 2 - 6 } & $1.179 \pm 0.005$ & $1.082 \pm 0.012$ & $0.909 \pm 0.002$ & $0.652 \pm 0.007$ & $0.402 \pm 0.005$ \\
45 & $0.980 \pm 0.001$ & $0.896 \pm 0.025$ & $0.696 \pm 0.003$ & $0.491 \pm 0.019$ & $0.291 \pm 0.004$ \\
35 & $1.125 \pm 0.004$ & $0.950 \pm 0.009$ & $0.820 \pm 0.020$ & $0.579 \pm 0.003$ & $0.368 \pm 0.020$ \\
\hline
\end{tabular}

were represented as mean $\pm \mathrm{SD}$

\section{TABLE-3}

STARCH DEGRADATION ACTIVITY OF AGAR-AGAR IMMOBILIZED $\alpha$-AMYLASE

\begin{tabular}{cccccc}
\hline & \multicolumn{5}{c}{ Concentration of soluble starch $(\% \mathrm{w} / \mathrm{v})$} \\
\cline { 2 - 6 } Temperature $\left({ }^{\circ} \mathrm{C}\right)$ & 2.4 & Absorbance & 0.8 \\
\cline { 2 - 6 } & $1.123 \pm 0.005$ & $1.033 \pm 0.011$ & $0.864 \pm 0.024$ & $0.616 \pm 0.004$ & $0.380 \pm 0.015$ \\
45 & $0.934 \pm 0.002$ & $0.856 \pm 0.021$ & $0.660 \pm 0.010$ & $0.463 \pm 0.004$ & $0.276 \pm 0.011$ \\
40 & $1.077 \pm 0.012$ & $0.912 \pm 0.001$ & $0.784 \pm 0.007$ & $0.550 \pm 0.006$ & $0.350 \pm 0.009$ \\
\hline 35 & \multicolumn{5}{c}{}
\end{tabular}

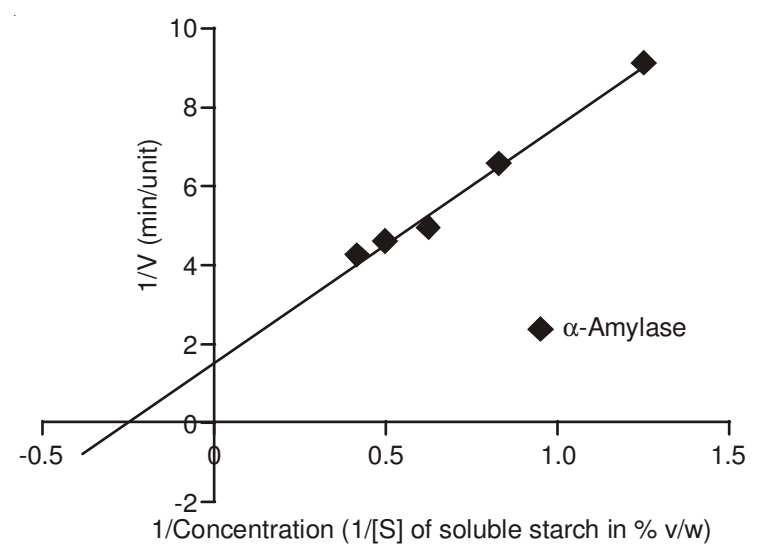

Fig. 3. Lineweaver burk plot of $\alpha$-amylase (free)

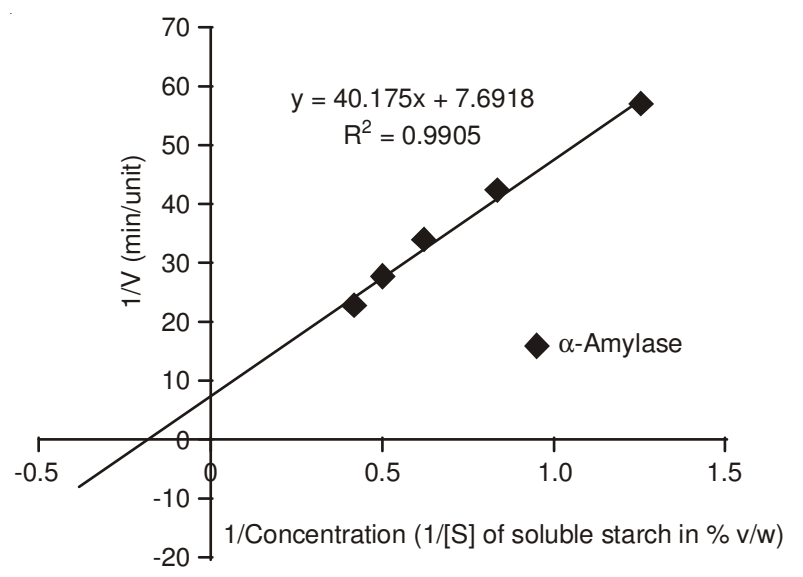

Fig. 4. Lineweaver burk plot of $\alpha$-amylase immobilized in sodium alginate

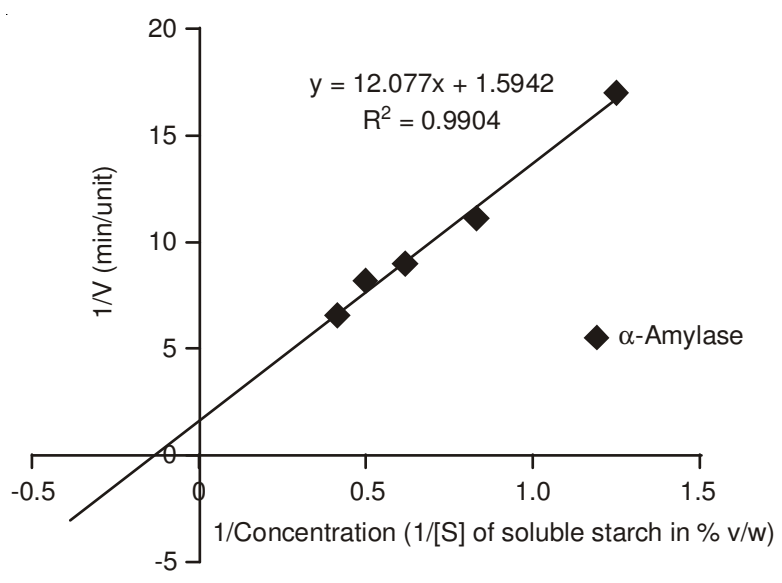

Fig. 5. Lineweaver burk plot of $\alpha$-amylase immobilized in agar-agar

$$
\begin{gathered}
\mathrm{k}=\mathrm{Ae}^{-\mathrm{E}_{\mathrm{a}} / \mathrm{RT}} \\
\mathrm{A}=\left(\frac{\mathrm{RT}}{\mathrm{Nh}}\right) \mathrm{e}^{\Delta \mathrm{S} / \mathrm{R}} \\
\mathrm{P}=\mathrm{e}^{\Delta \mathrm{S} / \mathrm{R}} \\
\Delta \mathrm{G}^{\mathbf{o}}=\Delta \mathrm{H}-\mathrm{T} \Delta \mathrm{S} \\
\Delta \mathrm{G}^{\mathbf{o}}=-\mathrm{RT} \ln \mathrm{K} \\
\mathrm{Z}=\frac{\mathrm{RT}}{\mathrm{Nh}} \\
\log \mathrm{k}=\log \mathrm{A}-\frac{\mathrm{E}_{\mathrm{a}}}{2.303} \frac{1}{\mathrm{RT}}
\end{gathered}
$$




$$
\begin{gathered}
\mathrm{k}=\left(\frac{\mathrm{RT}}{\mathrm{Nh}}\right) \mathrm{e}^{\Delta \mathrm{S} / \mathrm{R}} \mathrm{e}^{-\Delta \mathrm{H} / \mathrm{RT}} \\
\mathrm{k}=(\mathrm{PZ}) \mathrm{e}^{-\mathrm{E}_{\mathrm{a}} / \mathrm{RT}}
\end{gathered}
$$

where, $\mathrm{k}=$ the specific reaction rate, $\mathrm{R}=$ the gas constant (1.987 calories/deg mole) and $\mathrm{T}=$ the absolute temperature. $\mathrm{Z}$ $=$ the collision number, $\mathrm{N}=$ the Avogadro's number and $\mathrm{h}=$ the Planck's constant.

Arrhenius plots for free as well as immobilized $\alpha$-amylase are presented in Figs. 6-8 and the energy of activation $\left(\mathrm{E}_{\mathrm{a}}\right)$ was calculated from the slope. Subsequently, the Gibbs free energy $\left(\Delta G^{o}\right)$, entropy of activation $(\Delta S)$, equilibrium constant $(\mathrm{K})$, probability factor $(\mathrm{P})$ and other related values for free and immobilized (both in alginate and agar-agar) $\alpha$-amylase were computed using above mentioned equation and are presented in Table-4.

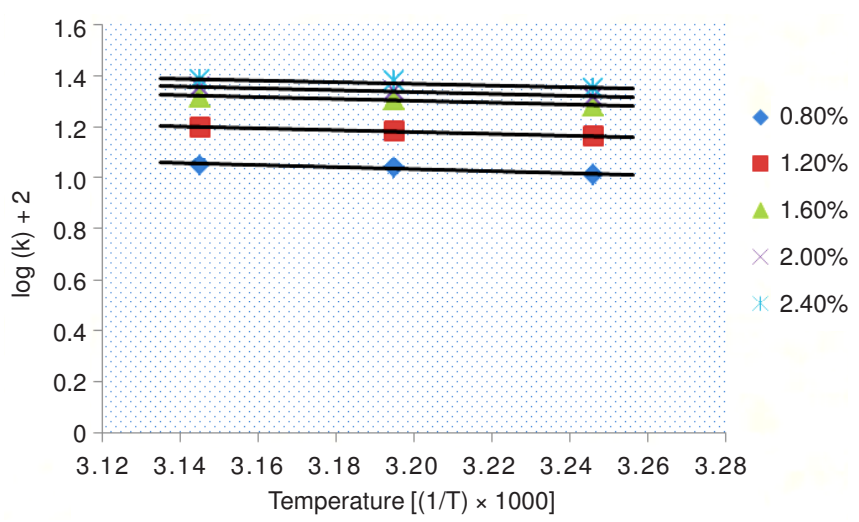

Fig. 6. Arrhenius plot of free enzyme ( $\alpha$-amylase)

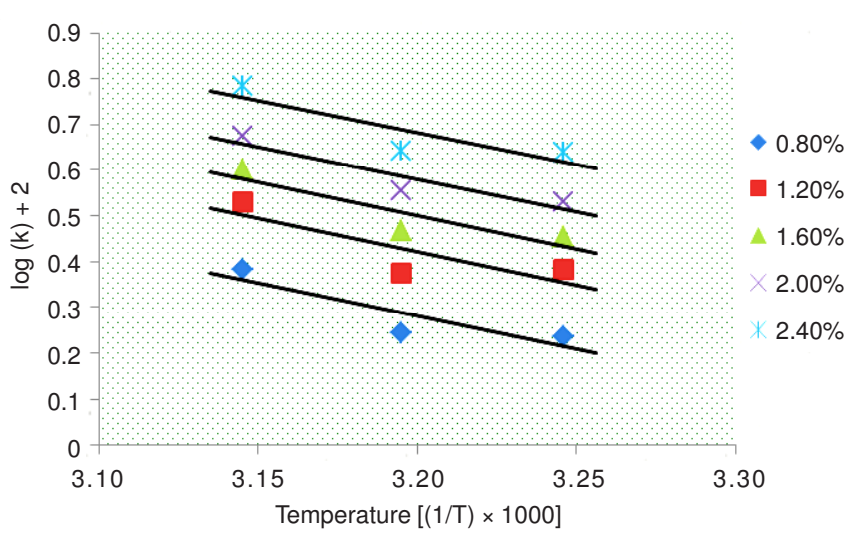

Fig. 7. Arrhenius plot of $\alpha$-amylase immobilized in sodium alginate

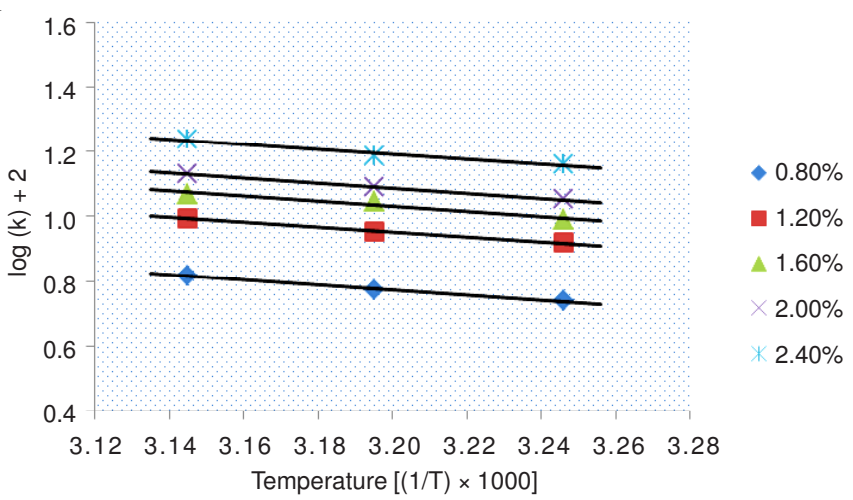

Fig. 8. Arrhenius plot of $\alpha$-amylase immobilized in agar-agar matrix

Lower the entropy values of the enzyme, more efficient are the formation of transition state or activated complex between enzyme-substrate ${ }^{18}$. The present study showed the lower entropy value for the free enzyme but higher entropy value for the immobilized enzyme indicating the good efficiency in the formation of transition state for free enzyme in comparison to immobilized enzyme. Computed $\Delta \mathrm{S}$ value for free enzyme $(-47.21 \mathrm{cal} / \mathrm{mol}-\mathrm{deg})$ is more negative than the alginate immobilized beads $(-33.59 \mathrm{cal} / \mathrm{mol}-\mathrm{deg})$ or agar immobilized beads $(-42.33 \mathrm{cal} / \mathrm{mol}-\mathrm{deg})$.

The reaction rate is proportional to formation of transition state complex by lowering the Gibb's free energy of activation $\left(\Delta \mathrm{G}^{\mathrm{o}}\right)$. The increasing value of $\Delta \mathrm{G}^{\mathrm{o}}$ in immobilized enzyme (17009 cal/mol for alginate immobilized and $16791 \mathrm{cal} / \mathrm{mol}$ for agar-agar immobilized) than in free form (16386 cal/mol) indicates that the enzyme substrate reaction is slower during immobilization.

Starch degradation activities of immobilized enzyme after different time of storage are presented in Table-5. It is evident from the table that the immobilized enzyme retained is activity even after 12 days. However the beads developed small fissure or softened or partially broken in the reaction mixture after more than 12 days storage.

Immobilized enzymes are generally more stable compared to free enzymes, due to the curtailment of their degrees of freedom (of rotation). Entrapped enzymes are unable to rotate freely. Prevention of the unfolding of its structure could be preserving its function ${ }^{13}$. The present work demonstrated a promising application potential of the alginate and agar-agar beads for enzyme immobilization.

\begin{tabular}{lccccccc}
\multicolumn{7}{c}{ TABLE-4 } \\
\multicolumn{1}{c}{ COMPUTED DATA } \\
\hline \multicolumn{1}{c}{ Enzyme } & $\mathrm{E}_{\mathrm{a}} / \Delta \mathrm{H}(\mathrm{cal} / \mathrm{mol})$ & $\mathrm{A}\left(\mathrm{s}^{-1}\right)$ & $\Delta \mathrm{S}(\mathrm{cal} / \mathrm{mol})$ & $\Delta \mathrm{G}^{\mathrm{o}}$ & $\mathrm{K}^{-1}$ & $\mathrm{~K}_{\mathrm{m}}(\% \mathrm{w} / \mathrm{v})$ \\
\hline Free $\alpha$-amylase & 1609 & $0.315 \times 10^{3}$ & -47.21 & 16386 & $0.361 \times 10^{-13}$ & 0.40 & $0.048 \times 10^{-9}$ \\
Alginate immobilized amylase & 6495 & $2.97 \times 10^{5}$ & -+33.59 & 17009 & $1.326 \times 10^{-12}$ & 0.52 & $4.55 \times 10^{-8}$ \\
Agar immobilized amylase & 3542 & $3.66 \times 10^{3}$ & -42.33 & 16791 & $1.883 \times 10^{-12}$ & 0.76 & $0.561 \times 10^{-9}$ \\
\hline
\end{tabular}

TABLE-5

STARCH DEGRADATION ACTIVITIES OF IMMOBILIZED $\alpha$-AMYLASE AFTER DIFFERENT TIME OF STORAGE

\begin{tabular}{cccc}
\hline & Absorbance on $1^{\text {st }}$ day & Absorbance on $6^{\text {st }}$ day & Absorbance on $12^{\text {st }}$ day \\
\hline Alginate immobilized enzyme & $0.491 \pm 0.019$ & $0.494 \pm 0.001$ & $0.496 \pm 0.015$ \\
Agar-agar immobilized enzyme & $0.463 \pm 0.004$ & $0.473 \pm 0.001$ & $0.480 \pm 0.015$ \\
\hline The data were represented as mean \pm SD. & & &
\end{tabular}




\section{ACKNOWLEDGEMENTS}

One of the authors (S. Pramanik) thank All India Council for Technical Education (AICTE), New Delhi for providing P.G. Scholarship during the study.

\section{REFERENCES}

1. T.H. Richardson, X. Tan, G. Frey, W. Callen, M. Cabell, D. Lam, J. Macomber, J.M. Short, D.E. Robertson and C. Miller, J. Biol. Chem., 277, 26501 (2002).

2. T. Kuriki and T. Imanaka, J. Biosci. Bioeng., 87, 557 (1999).

3. R. Gupta, P. Gigras, H. Mohapatra, V.K. Goswami and B. Chauhan, Proc. Biochem., 38, 1599 (2003).

4. D. He, Y. Cai, W. Wei, L. Nei and S. Yao, Biochem. Eng. J., 6, 7 (2000),

5. R.A. Messing, J. Am. Chem. Soc., 91, 2370 (1969).

6. R.A. Messing, Enzymologia, 38, 370 (1970).
7. W. Gaffield, Y. Tomimatsu, A.C. Olson and E.F. Jansen, Arch. Biochem. Biophys., 157, 405 (1973).

8. W.L. Stanley and A.C. Olson, U.S. Patent, P 736, 231 (1973).

9. P. Bernfeld and J. Wan, Science, 142, 678 (1963).

10. T.M.S. Chang, Science, 146, 524 (1964).

11. H.H. Weetall, Science, 166, 615 (1969).

12. G.R. Stark, Academic Press, New York (1971).

13. R.S.S. Kumar, K.S. Vishwanath, S.A. Singh and A.G.A. Rao, Process Biochem., 41, 2282 (2006).

14. A. Tanaka and E. Hoshino, J. Biosci. Bioeng., 96, 262 (2003).

15. G. Dey, B. Singh and R. Banerjee, Braz. Arch. Biol. Technol., 46, 167 (2003).

16. L.M. Hamilton, C.T. Kelly and W.M. Fogarty, Carbohydr. Res., 314, 251 (1998).

17. J.F. Kennedy, E.H.M. Melo and K. Jumel, Chem. Eng. Prog., 45, 81 (1990).

18. M. Riaz, R. Perveen, M.R. Javed, H. Nadeem and M.H. Rashi, Enzyme Microbiol. Technol., 41, 558 (2007). 